\title{
Sexual behaviour and sexually transmitted disease patterns in male homosexuals*
}

\author{
R R WILLCOX \\ From St Mary's Hospital, London
}

SUMMARY Male homosexual behaviour is not simply either "active" or "passive", since penileanal, mouth-penile, and hand-anal sexual contact is usual for both partners, and mouth-anal contact is not infrequent. A simplified method for recording sexual behaviour-a "sexual behaviour record (SBR)" - can be of value in determining the sites to be investigated and as a basis for further epidemiological questioning.

Mouth-anal contact is the reason for the relatively high incidence of diseases caused by bowel pathogens in male homosexuals. Trauma may encourage the entry of micro-organisms and thus lead to primary syphilitic lesions occurring in the anogenital area. Similarly, granuloma inguinale, condylomata acuminata, and amoebiasis may be spread from the bowel of the passive homosexual contact. In addition to sodomy, trauma may be caused by foreign bodies, including stimulators of various kinds, penile adornments, and prostheses.

\section{Introduction}

The male homosexual is very likely to contract most of the sexually transmitted diseases, including gonorrhoea, chlamydial infections, a number of viral conditions-for example, condylomata acuminata and herpes simplex-and especially syphilis, which he may acquire during the diverse techniques of sexual intercourse. From such behaviour numerous bowel conditions, such as amoebiasis and shigełlosis, and the viruses of hepatitis A or B are commonly spread within this group; indeed in some areas this is the predominant epidemiological pattern. ${ }^{12}$ In certain districts-the West End of London-nearly four-fifths of early syphilitic infections in men result from the homosexual act. ${ }^{3}$

\section{Sexual behaviour}

Sexual behaviour is very varied and in male homosexuals may involve contact between the penis, anus, mouth, and hand of either or both partners. Sometimes two or more organs may be involved in one sexual act; for example, the anus and mouth of one

*Paper read at the 30th General Assembly of the International Union against the Venereal Diseases and Treponematoses, East Berlin, June 1980

Address for reprints: Dr R R Willcox, Tideway, Lonsdale Road, London SW13

Accepted for publication 24 November 1980 partner ${ }^{1}$ and the penis of the other. Penile-hand contact is common for both partners. The roles are often reversed during the same sexual act, and mouth-anal contact is not at all uncommon for both partners, with the consequent almost inevitable risk of transfer of bowel pathogens.

Although routine visual examination of the mouth, anus, and rectum will detect clinically obvious conditions like syphilis, condylomata acuminata, and the sores of herpes simplex, this is not true of rectal gonorrhoea, which is frequently asymptomatic, and of oral gonorrhoea, which is normally so. The routine investigation of male homosexuals for gonorrhoea should, therefore, include the culture of samples from the penis, anus, and mouth, but this is a time-consuming procedure under busy clinic conditions. While it may be desirable to test these three sites in all male homosexuals at least once, sampling can be confined subsequently to those sites which the patient admits have been exposed to infection.

\section{SEXUAL BEHAVIOUR RECORD}

It has been, and still is, common practice to record male homosexual behaviour as "active" or "passive", although many male homosexuals alternate these roles with different partners or play a double role with the same partner. Because of this a "sexual behaviour record (SBR)" has been devised (table I), which can act as a diagnostic guide to which 
TABLE I Sexual behaviour record (SBR)

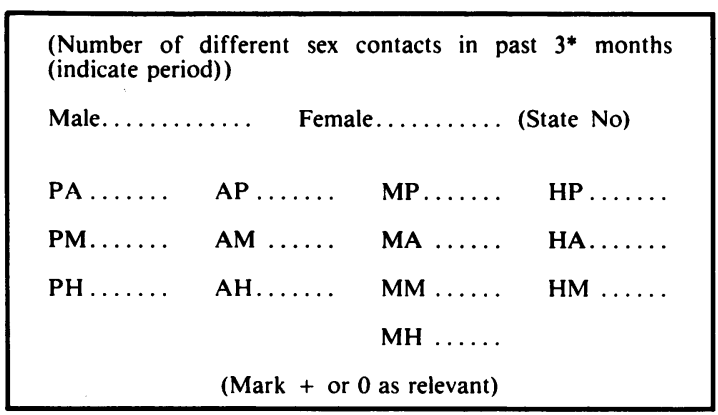

$\mathbf{P}=$ penis; $\mathbf{A}=$ anus; $\mathbf{M}=$ mouth $\mathbf{H}=$ hand

*If gonorrhoea is the only condition suspected, a one-month period is adequate.

sites should be investigated (principally for the gonococcus) and how intensively; it can also serve as a basis for further epidemiological questioning and action.

The first letter (table I) applies to the relevant anatomical part of the patient and the second to the site of its application to any one of the sexual contacts in the period under review. The form may be simplified by the omission of hand and appear as in table II. Such a record is concise, can be obtained quickly by the examining doctor, and lends itself to its basic framework being incorporated on a rubber stamp or in handwritten notes.

The method may be unnecessarily elaborate for non-promiscuous male homosexuals, and its modification for female patients, although suitable for the very promiscuous, is not so for the majority who admit to only one contact during the given period.

TABLE II Simplified version of the sexual behaviour record

\begin{tabular}{|llll|}
\hline \multicolumn{3}{c}{ Period 3/12 } \\
& M 5 & F 0 & (State No) \\
PA + & AP + & MP + \\
PM+ & AM 0 & MA 0 \\
& & MM + \\
\hline
\end{tabular}

$\mathrm{P}=$ penis $\mathrm{A}=$ anus $\mathrm{M}=$ month

$+=$ Yes; $0=$ no

\section{Trauma in disease patterns}

ANUS AND RECTUM

Some speculation still surrounds the specific mechanism of inoculation of the virus of hepatitis B among homosexuals. Likewise it has been suggested that the anal manifestations of granuloma inguinale result from self-inoculation of the area traumatised $\frac{\Phi}{\Phi}$ during sodomy or related practices with the organism, which was carried in the patient's bowel. ${ }^{4}$. This has also been postulated for condylomata $\Rightarrow$ acuminata ${ }^{5}$ and may apply to genital amoebiasis. It is $\stackrel{?}{?}$ also probable that anal chancres frequently invade? the site of pre-existing traumatic fissures.

Apart from the trauma produced by the act of $\frac{\overline{\bar{c}}}{\frac{1}{2}}$ sodomy itself and from fingernails in hand-anal con- $\stackrel{\mathbb{D}}{\Omega}$ tact, a wide range of foreign bodies-inserted into the rectum for sexual stimulation and gratifica- $\vec{O}$ tion-have caused serious trauma. ${ }^{2}$ An extreme? example is the human fist favoured by some more $\vec{\omega}$ elderly experienced homosexuals under the influence of drugs. ${ }^{6}$

MALE EXTERNAL GENITALIA

Possible trauma to the ano-rectal region, the penis, or adjacent areas can be caused by the various penile 의 adornments or prostheses used by some homosexuals $\overrightarrow{\vec{c}}$ who are influenced by sex magazines or catalogues $\subseteq$ (particularly those describing "leatherware") with a $\odot$ sado-masochistic bias. Examples include (fig 1): (1) $\overrightarrow{0}$ the so-called "cock and ball" rings"; (2) the more $\stackrel{\infty}{-}$ traumatic "spiky cock ring"; (3) the "boilermaker" " (two "cock" and one "ball" ring); (4) the "tenderiser"; (5) the "gates of hell" (in ground plan) showing its four leather straps and press studs; and (6) the same, with its added "slave lead".

Recently a homosexual male nurse well experienced in the contraction of sexually transmitted diseases presented an unusual appearance on routine examination for venereal disease (fig 2). The protrusion from his urethra proved to be a stainlesssteel ring (the "Prince Albert"), which entered the $\stackrel{\text { s? }}{=}$ terminal urethra to emerge adjacent to the frenum. The ring was removable like an earring and had a small perforated steel ball, which slid to and fro o within its small compass of motion along the external portion. The patient, who had chosen this item from 을 a catalogue, had had his urethra pierced under local $D$ anaesthetic by a doctor in Amsterdam at a cost of $£ 15$ 음 (approx US \$35 or DM62).

An advertisement in a male-orientated porno- 0 graphic magazine obtained in Hamburg (West $\mathrm{O}$ Germany) illustrated the following, which have not $N_{\omega}^{N}$ been seen in sex shops in London: (1) a ring through $\sigma$ a nipple ("Brustwarze"); (2) a rod with ballpoint 0 ends laterally through the glans penis ("Ampallang"); (3) a ring through the prepuce? ("Vorhaut"); (4) a ring through the perineum to ("Guiche"); (5) a rod with ballpoint ends vertically

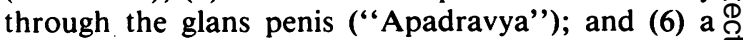
sketch of a naked man with his arms chained behind $\mathbb{D}$ his back to his neck, rings in his ears, nipples, and 

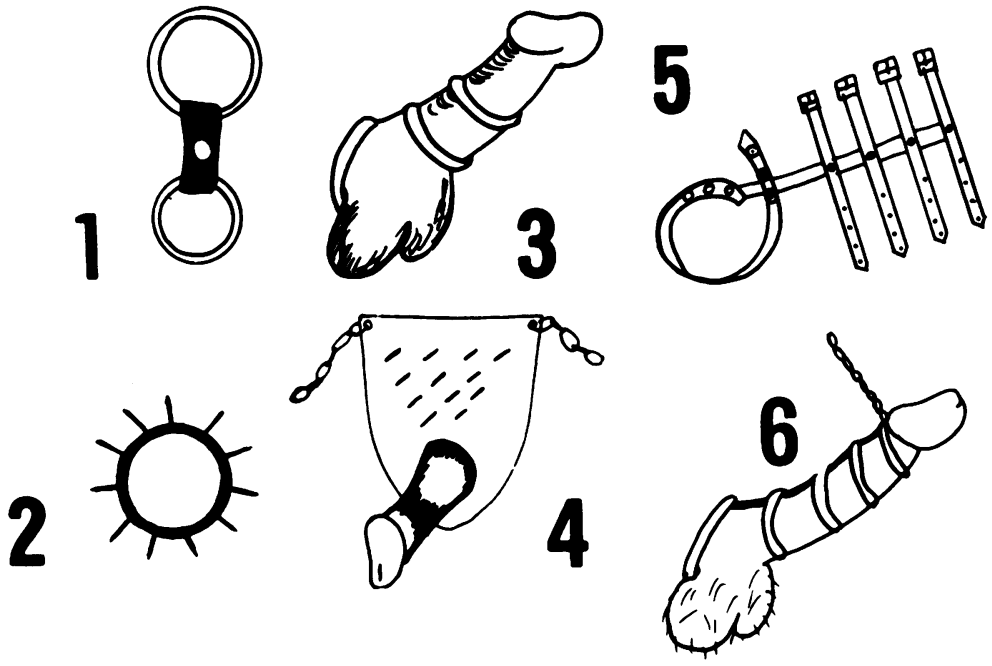

FIG 1 Various penile accessories. See text.

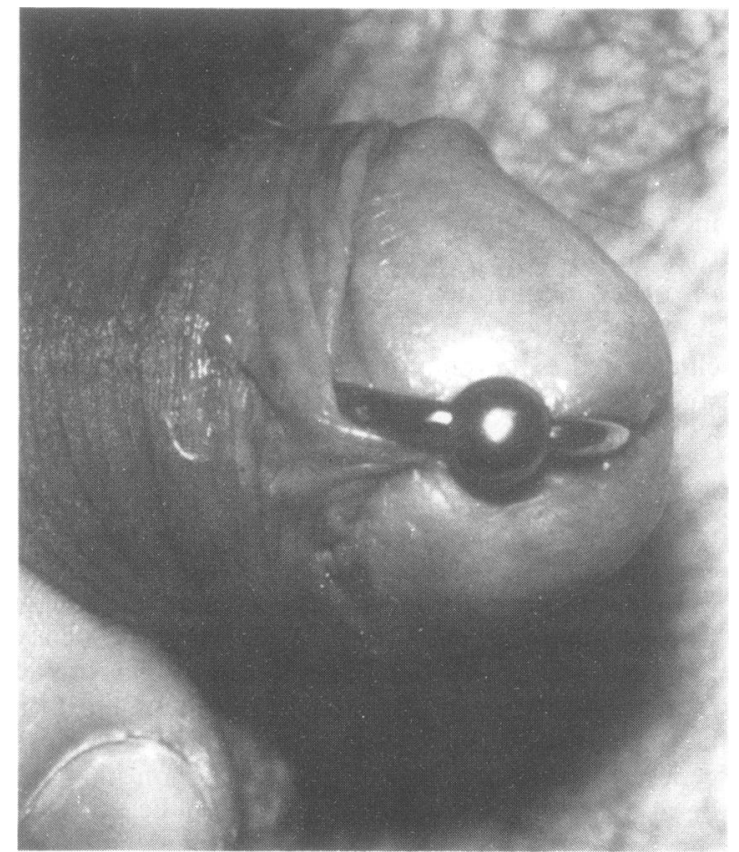

FIG 2 The "Prince Albert" ring.

perineum, and a padlock (with keyhole) entering and leaving the terminal urethra in the manner of a "Prince Albert" ring.

\section{Discussion}

Some of the examples described are more traumatic than others. It seems that at present they are used by only a small number of homosexuals (or that they are removed before the patients attend the clinics). Certainly in the large clinic at St Mary's Hospital, London, where there are many homosexuals, very few examples have been seen. Nevertheless, their use represents another method by which the rectum and anus can be injured and thus provide an entry for infection.

Thanks are expressed to Dr P N Cardew and the Department of Visual Communication, St Mary's Hospital, London, for the photograph, and to R M Coleman, director of Lydcare Ltd, for permission to use the drawings in fig 1 .

\section{References}

1. Mildran D, Gebb AM, William D. Venereal transmission of enteric pathogens in male homosexuals. JAMA 1977;238: 1387-9.

2. Willcox RR. The rectum as viewed by the venereologist. $\mathrm{Br} J$ Vener Dis 1981;57:1-6.

3. British Co-operative Clinical Group. Homosexuality and venereal disease in the United Kingdom. Br J Vener Dis 1980; 56:6-11.

4. Goldberg J, Bernstein R. Studies on granuloma inguinale. VI Two cases of perianal granuloma inguinale in male homosexuals. Br J Vener Dis 1964; 40:137-8.

5. Oriel JD. Anal warts and anal coitus. Br J Vener Dis 1971;47: 373-6.

6. Sohn N, Weinstein MA, Conchar I. Social injuries of the rectum. Amer J Surg 1977; 134:611-2.

7. Hooper A. Pricks for kicks: the penetrating art of erotic piercing. Forum 1980;6-8 Oct. 